Розділ І. Ціннісні орієнтири духовно-інтелектуального виховання, розвиток духовно-інтелектуальних якостей особистості в умовах співпраці й інклюзії

\title{
ПАТРІОТИЧНЕ ВИХОВАННЯ ОСОБИСТОСТІ ЯК ПЕДАГОГІЧНА ПРОБЛЕМА
}

\author{
Кульчицький В. Й.
}

доктор педагогічних наук, доцент, Тернопільський національний медичний університет імені І. Я. Горбачевського МОЗ України, м. Тернопіль, Україна

У статті обтрунтовано теоретико-методичні засади розвитку патріотичного виховання особистості, під якими розумісмо сукупність вихідних наукових положень, щзо визначають кониептуальні теорії, основні підходи, принциип впровадження форм і методів формування національно свідомої особистості, здатної до змічнення державності й забезпечення територіальної иілісності краӥни.

Ключові слова: виховання, патріотичне виховання, особистість, патріотизм.

The article substantiates the theoretical and methodological principles of patriotic education, which means a set of basic scientific principles that define conceptual theories, basic approaches, principles, implementation of forms and methods of forming a nationally conscious personality capable of strengthening statehood and ensuring the territorial integrity of the country.

Key words: education, patriotic education, personality, patriotism.

Патріотичне виховання є одним із пріоритетних напрямів у педагогічній доктрині України, оскільки сприяє формуванню у молоді високої патріотичної свідомості, готовності до виконання громадянського обов'язку.

Виховання $\epsilon$ конкретно-історичним та соціальним явищем, воно детермінується соціальним замовленням та враховує вимоги суспільства до молодого покоління. Це замовлення набуває відображення в нормативно-правових актах, програмах та різноманітних планах.

Нормативно-правова база 3 питань патріотичного виховання молоді в сучасній Україні є надзвичайно грунтовною та об'ємною. Так, зокрема, в Указі Президента України від 18.05.2019 № 286/2019 «Про Стратегію національно-патріотичного виховання», зазначено, що «в основу системи національно-патріотичного виховання покладено ідеї зміцнення української державності як консолідуючого чинника розвитку суспільства, формування патріотизму та утвердження національних цінностей» [7].

Аналіз нормативно-правової бази з питань патріотичного виховання молоді в сучасній Україні дає підстави говорити про грунтовний підхід щодо вирішення цієї проблеми. Однак, на наш погляд, суттєвою вадою, 
яка притаманна процесу патріотичного виховання молоді на сучасному етапі, є виконання зазначених нормативних документів на регіональному рівні не в повному обсязі, а подекуди й повне їх ігнорування.

На сьогодні в педагогічній науці патріотичне виховання розглядають як історично зумовлену сукупність ідеалів, переконань, а також традицій, звичаїв та інших форм соціальної поведінки, що спрямовані на організацію життєдіяльності молоді, у процесі якої опановується духовна й матеріальна культура нації, а також формується національна свідомість і духовна єдність різних поколінь. І. Бех зазначає, що патріотичне виховання передбачає «широкі знання конституційних і правових норм, державної політики, сформованість патріотичних думок та дієвих заходів з відстоювання національних форм життєдіяльності і поведінки в усіх сферах суспільного життя» [1].

Таким чином, патріотичне виховання молоді посідає важливе місце та пов'язане з багатьма напрямами виховання. У межах патріотичного виховання предметом уваги на різних рівнях є «національна ідея, національна культура, рідна мова, історія народу і держави, самовизначення, самоідентифікація, категорії Батьківщини (мала і велика Батьківщина), лідери та герої народу, нації, держави, рідний край» [5, с. 17-20].

На сучасному етапі розвитку патріотичного виховання важливим є дотримання єдності поглядів на проблему виховання громадянина і патріота незалежної України, а також гарантування єдності навчання, виховання й розвитку молодого покоління.

Суспільство потребує демократичного гуманістичного патріотизму. Демократичний означає простий для розуміння і властивий широким верствам населення. Гуманістичний вказує на дотримання національних та загальнолюдських цінностей та інтересів, повагу конституційних прав і свобод людини та громадянина. Єдність демократичного й гуманістичного патріотизму має стати надійним фундаментом громадянського суспільства.

У контексті подальшої розбудови суспільства виникає потреба у формуванні соціально активної, творчої особистості патріота, від діяльності якого в майбутньому значною мірою залежатиме духовний розвиток і добробут Української держави [4, с. 37].

Чітке визначення ідеалів патріотичного виховання й ціннісних орієнтацій молоді сприятиме оптимізації цього важливого напряму виховання та подоланню негативних явищ у суспільній свідомості, 
Розділ І. Ціннісні орієнтири духовно-інтелектуального виховання, розвиток духовно-інтелектуальних якостей особистості в умовах співпраці й інклюзії

зокрема відсутності в декого з молодих людей чітких світоглядних основ поведінки й діяльності, байдужості до державних проблем, низького рівня моральності та культури.

Разом із тим необхідно відзначити, що основою патріотизму є певна система суспільних ідей, які визначають основні принципи розвитку нації. Саме тому патріотичне виховання молоді $є$ актуальним, соціально важливим завданням, зумовленим потребами педагогічної теорії та практики [6, с. 24-27].

Слід констатувати, що виховання патріотизму — це складний процес, i велике значення в ньому має освіта, яка дає молоді громадянські засади, потребує від них активності, творчості та соціальної зрілості. Соціально-педагогічні основи патріотичного виховання формують світогляд молодої людини, іiі громадянську свідомість, соціальну зрілість. Завдяки освіті молода людина стає справжнім громадянином своєї держави, розуміє своє призначення в суспільно-політичному житті.

Таким чином, загальне завдання педагогічної діяльності в освітньому процесі полягає у створенні умов для гармонійного розвитку патріотичної особистості, підготовці молодого покоління до праці й інших форм участі в житті суспільства. Реалізується це завдання шляхом організації особистісно розвивального середовища, керування різноманітними видами діяльності вихованців і побудови правильної взаємодії.

Саме тому, на нашу думку, слід виділити такі концептуальні положення патріотичного виховання молоді, як-от: служіння Вітчизні, історична й соціальна пам'ять, спадкоємність духовного досвіду поколінь, соціокультурна ідентифікація, гордість і великодушність в осмисленні соціокультурної реальності історичного минулого, соборність у вихованні духовних основ патріотизму, імплікації традицій і інновацій у патріотичному вихованні [2].

Необхідно відзначити, що патріотичне виховання як педагогічний процес має свої особливості: двосторонній характер; безперервність та тривалість; взаємозв'язок, взаємодоповнюваність процесів виховання, самовиховання та перевиховання; багатофакторність різноманітних виховних впливів (батьки, друзі, навколишнє середовище, засоби масової інформації тощо); латентний (прихований) характер результатів виховання; концентризм формування патріотичних якостей особистості з урахуванням індивідуальних, психічних і вікових можливостей; різноманітність форм, методів і прийомів виховання. 
Сферами патріотичного виховання є спілкування та діяльність, однак виховна дія відбувається тільки шляхом взаємодії особистості 3 різними об'єктами життя у процесі виникнення різноманітних виховних ситуацій. Розрізняють такі види виховної взаємодії: педагогічна (вихователь - вихованець); взаємна (вихователь - вихованець вихованці - ровесники); предметна (ставлення до предметів культури); ставлення вихованця до самого себе [3].

Відтак, сучасні педагоги, науковці визнають, що патріотичні почуття є могутньою і непереможною духовною силою кожного народу. Суть справи полягає в тому, що без національно-свідомого, патріотично налаштованого фахівця неможливо не лише підняти, а й зберегти державу. Таким чином, одним із найважливіших завдань педагогічної теорії і практики є патріотичне виховання, яке повинно здійснюватися, на нашу думку, ще з раннього дитинства. Патріотична громадська активність особистості повинна постійно підвищуватись у процесі виховання, самовиховання й самовдосконалення, переростати відповідно до вікових особливостей у громадсько-політичну, державницьку діяльність.

\section{Список використаних джерел:}

1. Бех І. Виховання особистості : в 2 т. Київ : Знання, 2003. Т.1.: Особистісно-орієнтований підхід: теоретико-технологічні засади : навч.-метод. видання. $280 \mathrm{c}$.

2. Жаровська О. П. Патріотичне виховання студентів в освітньо-виховному середовищі педагогічного університету: дис. ... канд. пед. наук: 13.00.07 / Вінницький державний педагогічний університет імені М. Коцюбинського. Вінниця, 2015. 290 с.

3. Зайченко I. В. Історія педагогіки : в 2 т. . Київ : Слово, 2010. Т. ІІ. Школа, освіта і педагогічна думка в Україні. 1032 с.

4. Кузьмінський А., Омеляненко В. Педагогіка у запитаннях і відповідях : навч. посіб. Київ: Знання, 2006. 311 с.

5. Пономаренко Л. Виховання громадянськості у молодших школярів. Початкова. школа. 2001. № 3. С. 17-20.

6. Сухомлинська О. Сучасні цінності у вихованні. Шлях освіти. 1996. № 1. C. 24-27.

7. Указ Президента України від 18.05.2019 № 286/2019 «Про Стратегію національно-патріотичного виховання». URL: https://zakon. rada.gov.ua/ laws/show/286/2019 (дата звернення: 09.10.2021). 